Article

\title{
Assessment of Quantitative Standards for Mega-Drought Using Data on Drought Damages
}

\author{
Youngseok Song ${ }^{1}(\mathbb{D}$ and Moojong Park $2, * \mathbb{C}$ \\ 1 Department of Civil Engineering and Landscape Architectural, Daegu Technical University, \\ Daegu 42734, Korea; kind711@hanmail.net \\ 2 Department of Aeronautics and Civil Engineering, Hanseo University, Seosan 31962, Korea \\ * Correspondence: mjpark@hanseo.ac.kr; Tel.: +82-41-660-1051
}

Received: 5 April 2020; Accepted: 27 April 2020; Published: 29 April 2020

check for updates

\begin{abstract}
Among natural disasters, droughts can affect a large area for a prolonged period of time. If a drought happens, an appropriate response requires a lot of time and manpower from beginning to end, and continuous management is necessary for further prevention. Using data on drought damages from 1900 to 2018 in 148 countries in six continents around the world, this study was able to set quantitative standards for mega-droughts. According to data on the status of annual drought damages, the frequency of drought damages (1900-2018) and the subsequent damage costs (1965-2018) are increasing, while human losses (1900-2018) are decreasing. Additionally, Africa had the highest frequency of drought damages, while Africa and Asia were ranked at the top of the list in terms of human losses and damage costs, respectively. Droughts persisted for continuous periods ranging from 1 to 17 years, and the total number of cases involving drought damage was estimated to be 600 in total, with total human losses of 11,731,294 people and total accumulated damage costs of $\$ 17,367,007,000$. This study provided quantitative standards for the frequency of drought damages, human losses, and damage costs for mega-droughts in consideration of continuous drought periods. This study set the quantitative standards for a mega-drought as follows: (1) if drought damages continue to occur in a country for more than seven years, (2) if human losses continue to occur in a country for more than seven years, and (3) if mean annual damage costs of $\$ 17,000,000$ continue to occur in a country for more than seven years.
\end{abstract}

Keywords: mega-drought; drought damage; natural disaster; drought continuous period; CRED

\section{Introduction}

Due to the influence of climate change induced by global warming, the whole world is experiencing changes in hydrologic phenomena. Not only are some countries experiencing a change from a cool temperate climate to a subtropical climate, but the frequency of extreme climate events is also increasing. Among recent natural disasters resulting from climate change, droughts that have persisted for continuous periods of many years have caused colossal damages in California in the U.S, Australia, and Italy and brought the problem of mega-droughts to the forefront of global issues.

Droughts take place periodically and affect far-flung areas, and it is difficult to predict the exact location and time of possible drought damages. In addition, as their uncertain starting points and causes defy exact prediction, they have prompted many heated debates [1,2]. In recent studies, it has been reported that the major cause of droughts is climate change and that global warming is aggravating drought damages [3-12]. A mega-drought is an extremely severe dry spell that has persisted for several years during the 20th century and that is expected to persist for decades. Recently, droughts have occurred in the southwestern region of the United States as well as Africa and Chile, and it has been reported that droughts are closely related to the extinction of the Angkor civilization [13-18]. Further, 
mega-droughts are expected to occur and cause substantial damages in the southwestern region of the United States, due to the influence of recent climate change $[19,20]$.

In the western United States, droughts with a continuous period of several years occurred from 2014 to 2015 and had a major impact on the economy, environment, and society of the United States. The water levels of the Colorado River and reservoirs receded to half and the decreased water level in Lake Powell caused an electric generator to shut down [21]. These droughts also caused a decrease in agricultural output as well as a decline in the water levels of rivers, lakes, reservoirs, and underground water. An analysis of the effect of droughts occurring in the Western United States on plant stress found that drought damages from 2006 to 2015 had a greater impact on plant trees than those occurring over any other periods of time. Based on these results, the study defined droughts which persist for a continuous period of 10 years as mega-droughts [22]. It was assumed that the occurrence of a prolonged dry spell for 10 years was sufficient to define a drought as a mega-drought. However, this definition cannot be universally applied to the entire world, due to factors such as the regional limitations of a nation, short periods of data analysis, and low frequency of drought. Thus, more analyses need to be carried out to support the definition.

In the northwestern America region, drought damages with a continuous period of 10 years have recently occurred periodically, including the Dust Bowl in the 1930s and drought damages in the early 2000s [9,23-26]. Paleo-climatologic studies have confirmed that drought damages with a continuous period of 10 years occurred periodically in California between 900 to 1300 [1,19,27-29]. The results of various analyses using hydrological factors, Palmer Drought Severity Index (PDSI), rainfalls, and paleoclimatology have shown that these droughts in California met the necessary extreme conditions $[2,27,30,31]$. Many different studies have indicated that droughts with mega-drought traits have occurred periodically in the past. However, these results confirmed consistency only in terms of hydrological indicators of drought damages and failed to establish quantitative standards for mega-drought.

As precipitation shortfalls persisted in the central region of Chile, the water levels of reservoirs went down and the durations of wildfires increased [32]. The study investigated the trend of anthropogenic climate change and natural climate change over a five-year period from 2010 to 2014. According to the results, northwestern America showed similar trends, including similar mega-drought characteristics and precipitation [22,33]. Some studies have reported that during the mega-drought in the central region of Chile starting from 2010, wildfires broke out in 2016 and 2017 and caused colossal damages [34]. The affected areas for the two years were ten times larger than those of the mid-1970s, indicating a correlation between mega-drought and wildfire in terms of fire size and land use [35-37]. It was reported that the characteristics of precipitation in the case of drought damages were similar to the lightweight traits in the northwestern Americas, which could be defined as a mega-drought. However, as only hydrological influence was reflected when establishing the definition of mega-drought based on their matched precipitation traits, additional analyses need to be conducted on drought damages in more diverse countries and damage cases.

The Iberian Peninsula in the southwestern corner of the European continent, where the Douro River, Tagus River, and Guadiana River are located, is considered to be a hydrologically important area, and the region is now facing water shortages due to increased variability in precipitation. Portugal and Spain, both part of the Iberian Peninsula, have suffered the continuous occurrence of drought damages since 1940, and their frequency of drought damages has increased in the late 20th century [38-41]. Current climate forecasting will cause frequent droughts in the future due to heat waves, and the agricultural system and priority to increase the productivity of crops are calculated considering the Emergency Events Database (EM-DAT) by country [42]. To analyze the potential effects of drought damages resulting from climate change in the future, the Coupled Model Intercomparison Project phase (CMIP5) for the Representative Concentration Pathways (RCP) 8.5 was used to estimate Drought Severity Index (DSI)-12 through 2100. The results showed that $80 \%$ of the river basins located in the Iberian Peninsula were likely to be affected by mega-droughts, and that extremely severe droughts 
were expected to continue to occur until 2100 [43]. A comparison with the past data on drought damages suggested that mega-droughts are likely to continue to occur in the future due to the influence of climate change. However, they did not present quantitative standards on the frequency of drought damages and continuous periods, which could be used to predict the occurrence of mega-drought in the future.

In this study, we used data on drought damages occurring around the world from 1900 to 2018 to present quantitative standards for mega-drought. This study intended to identify the characteristics of drought damages, human losses, and damage costs based on global drought damage data, and to estimate the status of drought damages by continent, including Asia, the Americas, Europe, Africa, Oceania, and the South Pole. In addition, the study aimed to set quantitative standards for mega-droughts, including the frequency of drought damages, human losses, and damage costs in consideration of continuous periods of drought.

\section{Materials and Methods}

\subsection{Data on Global Drought Damages}

The Centre for Research on the Epidemiology of Disasters (CRED) has been active for over 40 years in the fields of international disaster and conflict health studies, promoting activities linking relief, rehabilitation, and development. The CRED not only addresses disaster-induced health and conflict problems but also promotes research, training, and technical expertise on humanitarian emergencies, particularly in public health and epidemiology (Figure 1). The Emergency Events Database (EM-DAT), a project operated by the CRED, manages disaster damage data to improve preparedness for and responses to disaster occurrence, and collects data from various organizations including United Nations (UN) agencies, Non-Governmental Organization (NGOs), insurance companies, research institutes, and media organizations.

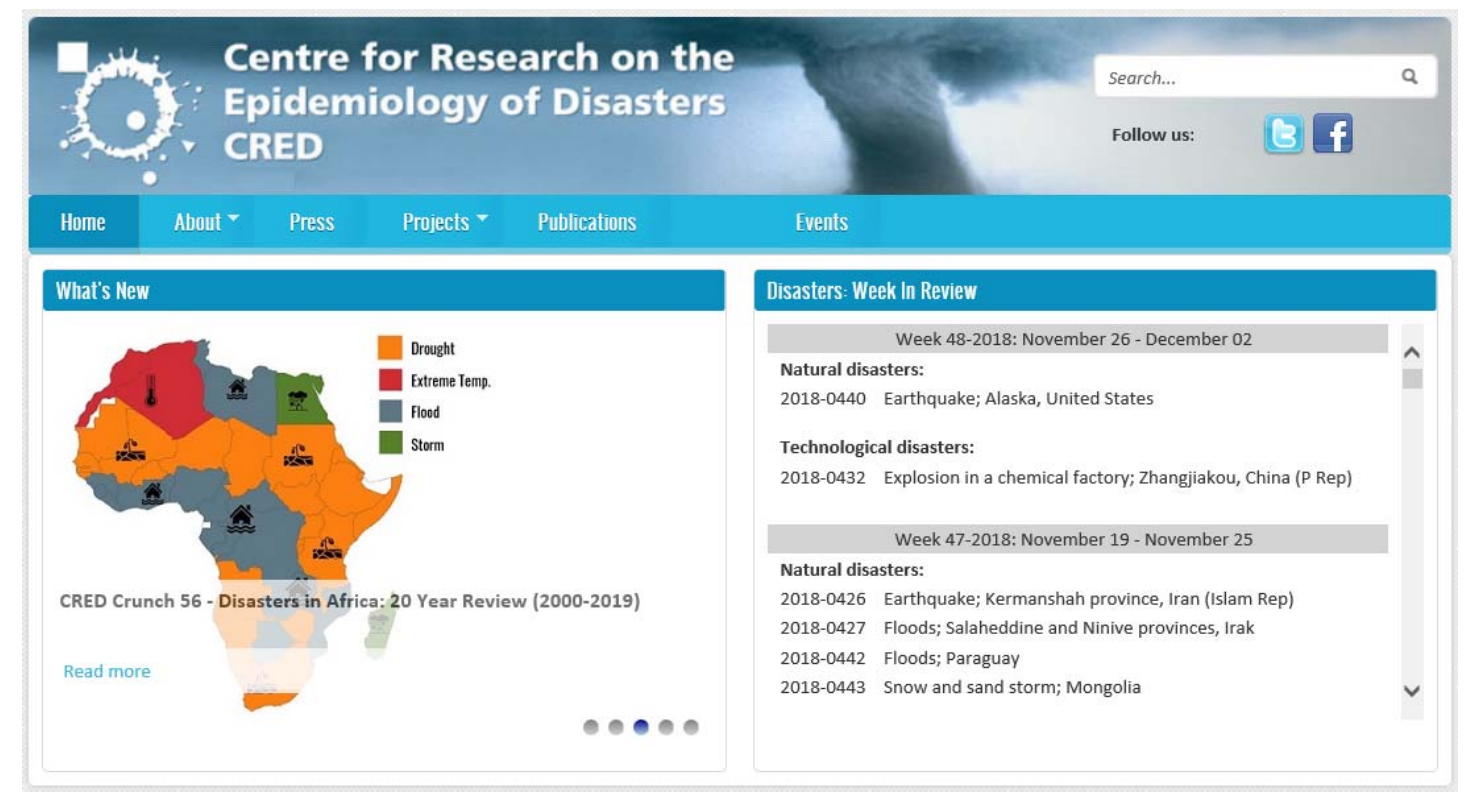

Figure 1. Centre for Research on the Epidemiology of Disasters (CRED: https://www.cred.be/).

The EM-DAT classifies natural disasters into biological, climatological, geophysical, hydrological, and meteorological subgroups as well as 11 disaster types to estimate the status of drought damages. The criteria of their disaster data include the occurrence of more than 10 human deaths, more than 100 human casualties, the declaration of a national emergency, and the need for international support. 
Here, Influence of human losses includes food, water, shelter, medical assistance and injuries in the disaster occurrence.

This study used data on the status of drought damages by country from 1900 to 2018, which were collected from natural disaster damage data provided by the CRED through the EM-DAT. The data on drought damages were collected by surveying and analyzing the frequency of drought damages, human losses, and damage costs.

\subsection{Characteristics of Drought Damages}

The frequency of global drought damages from 1900 to 2018 was estimated to be 1215 cases in total, and 146 countries were found to experience the occurrence of more than one drought (Figure 2). The mean annual number of global drought damages was estimated at fewer than two cases before 1960, except for the occurrence of approximately 10 cases in both 1910 and 1940. The frequency of drought damages has continued to increase after 1960 due to industrialization and climate change, and the trend line of drought damages has shown a steep increase. In the box-plot distribution of drought occurrence frequency, the first quartile $(25 \%)$ was set at two cases, the second quartile (median) was set at 11 cases, and the third quartile (75\%) was set at 20 cases. The mean annual frequency of global drought damages from 1900 to 2018 was estimated to be approximately 14 cases, with the range from a minimum of one case to a maximum of 53 cases.

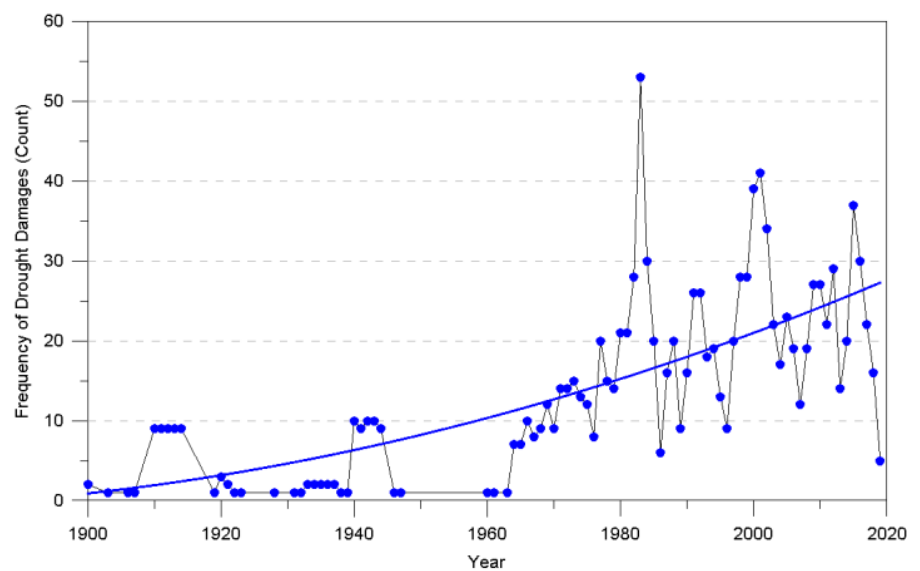

(a)

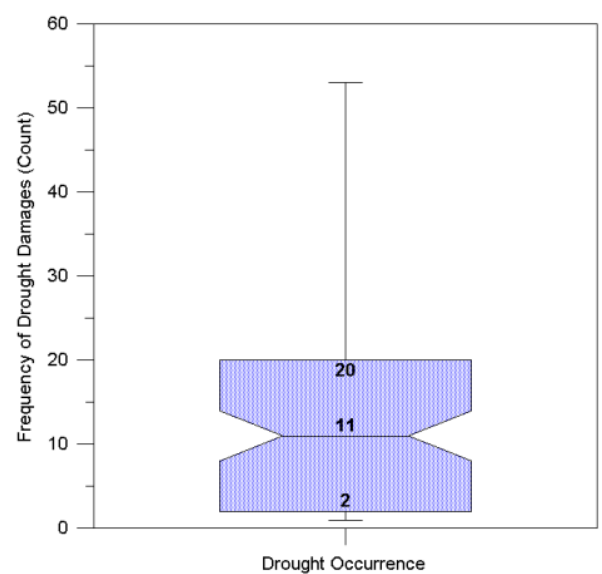

(b)

Figure 2. Centre characteristics of global drought damages (from CRED, 2019): (a) frequency of drought damages by year, (b) distribution of the frequency of drought damages.

In total, 146 countries have experienced the occurrence of more than one drought from 1900 to 2018, with 32 countries in the Americas, 48 countries in Africa, 36 countries in Asia, 21 countries in Europe, and 11 countries in Oceania (Figure 3). In terms of the frequency of drought damages by continent, there were 673 cases in Africa, and the most affected country in the continent was Mauritania with 39 cases. There were 229 cases in the Americas, and the most affected country in the continent was Brazil with 22 cases. There were 218 cases in Asia, and the most affected country in the continent was China with 34 cases. There were 56 cases in Europe, and the most affected country in the continent was Spain with 11 cases. Finally, there were 39 cases in Oceania, and the most affected country in the continent was Australia with 17 cases. The frequencies of drought damages by country and by continent are presented in Table A1. 


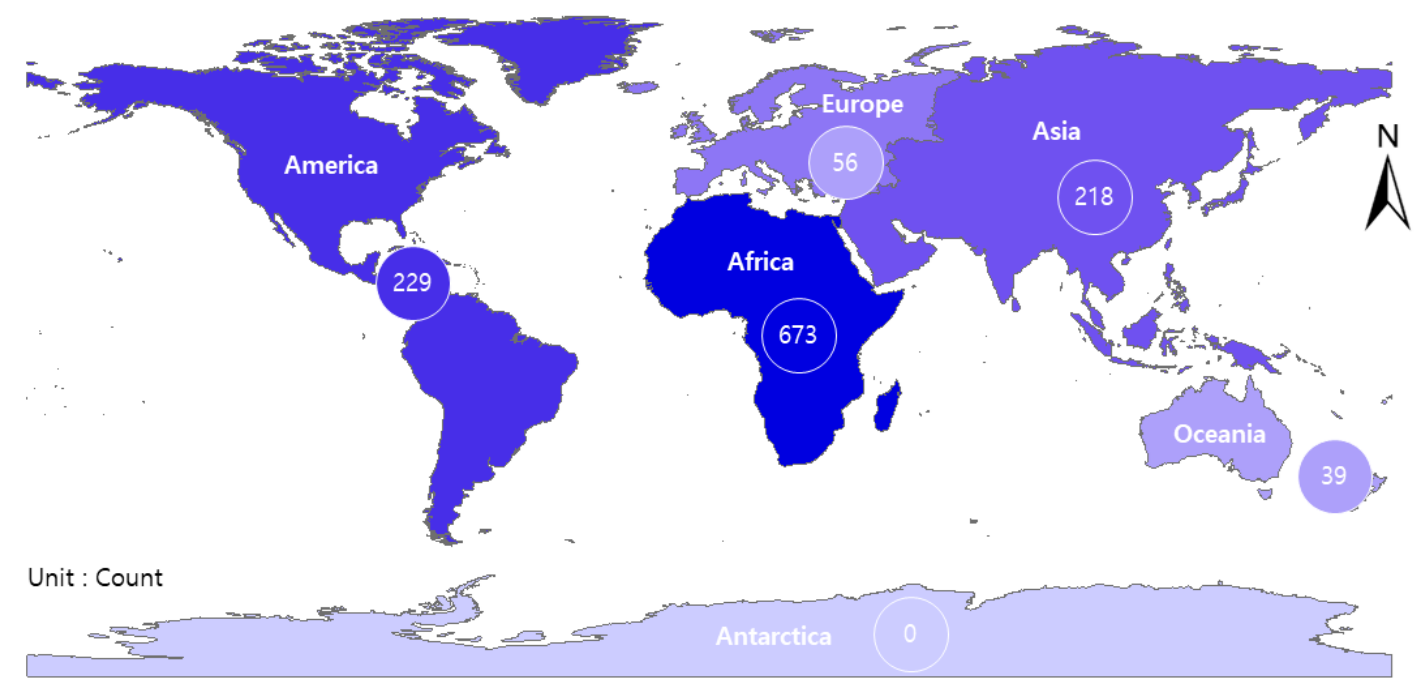

Figure 3. Characteristics of the frequency of drought damages by continent (1900 2018).

In terms of the frequency of global drought damages at an interval of 10 years, the number of drought damages before 1960 ranged from a minimum of 1 to a maximum of 40 cases (Table 1 ). However, most of these occurred in Africa, with a range from a minimum of 9 cases to a maximum of 37 cases, while the other continents experienced an occurrence of less than one time. After 1960, the number increased to 64 cases between 1961 and 1970, to 146 cases between 1971 and 1980, and to 219 cases between 1981 and 1990. The results also showed that the frequency of drought damages has increased by two or three times over the last 30 years. The frequency of drought damages increased around the world to more than 200 cases for each of the periods between 1991 to 2000, between 2001 and 2010, and between 2011 and 2018. The frequency of global drought damages from 1900 to 2018 was estimated to be 1215 times, with Africa experiencing 673 cases (approximately 55\%), Asia with 218 cases (approximately 18\%), the Americas with 229 cases (approximately 18\%), Europe with 56 cases (approximately 5\%), and Oceania with 39 cases (approximately 5\%).

Table 1. Status of global drought damages by continent.

\begin{tabular}{cccccccc}
\hline \multirow{2}{*}{ Year } & \multicolumn{7}{c}{ Number of Drought Occurrences (Count) } \\
\cline { 2 - 7 } & Asia & Americas & Europe & Africa & Oceania & South Pole & Sum \\
\hline $1900-1910$ & 1 & - & - & 13 & - & - & 14 \\
$1911-1920$ & 1 & 2 & - & 37 & - & - & 40 \\
$1921-1930$ & 1 & 3 & 1 & - & - & - & 5 \\
$1931-1940$ & - & 15 & - & 9 & - & - & 24 \\
$1941-1950$ & 3 & - & - & 37 & - & - & 40 \\
$1951-1960$ & 1 & - & - & - & - & - & 1 \\
$1961-1970$ & 17 & 14 & - & 30 & 3 & - & 64 \\
$1971-1980$ & 33 & 17 & 2 & 89 & 5 & - & 146 \\
$1981-1990$ & 30 & 31 & 14 & 140 & 4 & - & 219 \\
$1991-2000$ & 50 & 40 & 21 & 102 & 13 & - & 226 \\
$2001-2010$ & 49 & 52 & 11 & 127 & 2 & - & 241 \\
$2011-2018$ & 32 & 55 & 7 & 89 & 12 & - & 195 \\
\hline Sum & 218 & 229 & 56 & 673 & 39 & - & 1215 \\
\hline
\end{tabular}

\subsection{Characteristics of Drought-Induced Human Losses}

The total number of global drought human losses from 1900 to 2018 was estimated to be 11,731,294 people in total, and among the 146 countries with the occurrence of more than one drought, 30 countries experienced human losses (Figure 4). In this study, human losses were applied as the condition of 
human casualties. Regarding drought human losses, large scale human losses occurred at an interval of 20 years before 1960 but did not happen after 1960, except for a relatively large number of human losses in the early 1960s and the early 1980s. In terms of human losses at an interval of 10 years, the number of drought human losses was estimated to be between 3,000,000 and 1,000,000,000 people before 1960, which declined to 500,000 people in 1960 and further declined to 200,000 people in 1980 . The number of human losses has been declining at a steady pace since 1990, except for 2040 people in 1991 and 10,000 people in each of 2010 and 2011, with a range from a minimum of 2 people to a maximum of 702 people. In the box-plot distribution of human losses by droughts, the first quartile $(25 \%)$ was set at 126 deaths, the second quartile (median) was set at 10,000 deaths, and the third quartile (75\%) was set at 23,001 deaths. The mean annual number of human losses from 1900 to 2018 was estimated at approximately 213,000 people, with a range from a minimum of 2 people to a maximum of $3,000,000$ people.

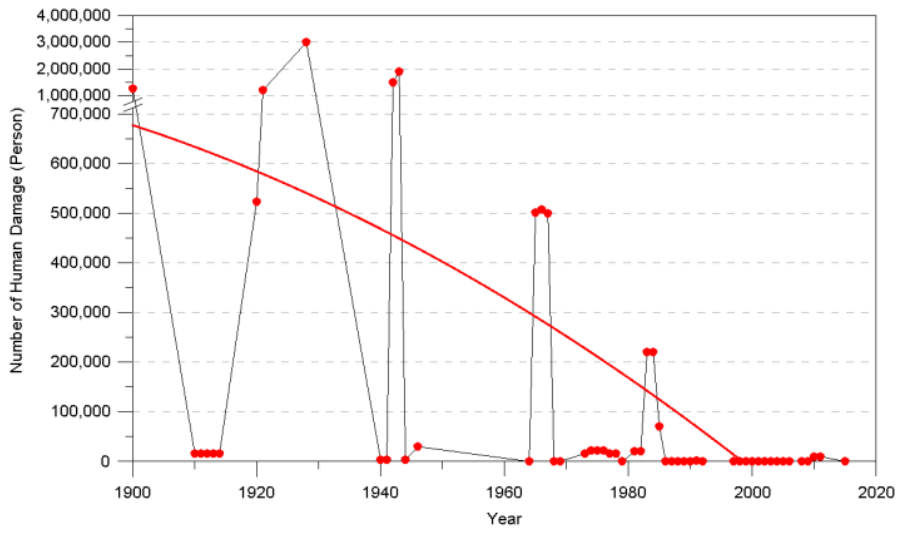

(a)

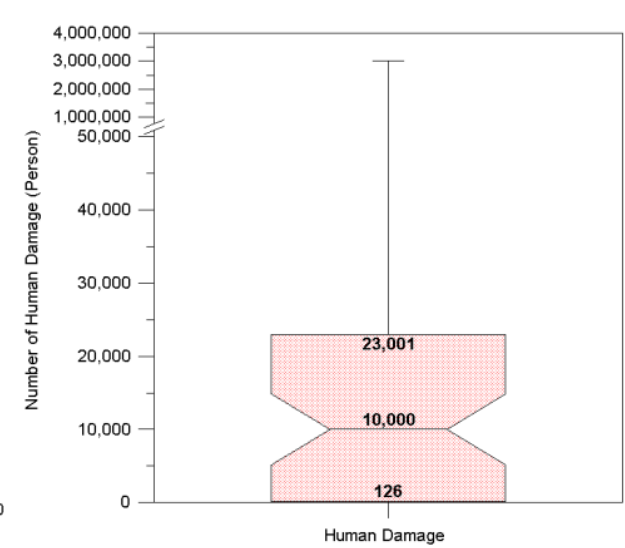

(b)

Figure 4. Characteristics of human losses by global droughts: (a) drought human losses by year, (b) distribution of drought human losses.

In terms of drought human losses by country from 1990 to 2018, 30 countries around the world had more than one drought. Classified by continent, there were 3 countries in the Americas, 16 countries in Africa, 7 countries in Asia, 2 countries in Europe, and 2 countries in Oceania (Figure 5). In terms of drought human losses by continent, the Americas experienced 77 deaths, and the most affected nation in the continents was Guatemala with 41 deaths. Africa experienced 867,131 deaths, and the most affected nation in the continent was Ethiopia with 402,367 deaths. Asia experienced 9,663,400 deaths, and the most affected nation in the continent was India with 4,250,320 deaths. Europe experienced 1,200,002 deaths, and the most affected nation in the continent was Russia with 1,200,000 deaths. Oceania experienced 684 deaths, and the most affected nation in the continent was Australia with 600 deaths. The statuses of drought human losses are presented in Table A1 by continent and by country.

When global drought human losses were calculated at an interval of 10 years, it was found that the number of human losses before 1970 fluctuated steeply at an interval of 20 years with a range of 1 to 4,000,000 deaths. However, the death toll has continued to decline since 1970 to 100,000-500,000 deaths between 1971 and 1990, and to approximately 10,000 deaths between 1991 and 2018 (Table 2). Drought-based human losses showed an overall declining trend from 1990 to 2018 but fluctuated sharply at an interval of 10 years. In addition, human losses by year were heavily concentrated in one continent, and the number of human losses in either Asia or Africa accounted for the overwhelming majority of cases. In terms of the characteristics of drought human losses, the total number of global drought human losses from 1900 to 2018 was estimated at 11,731,294 people. The characteristics of drought human losses by continent indicated that Africa suffered 867,131 deaths (7.4\%), Asia suffered 9,663,400 deaths (82.4\%), Europe suffered 1,200,002 deaths (10.2\%), the Americas suffered 77 deaths (about 1\%), and Oceania suffered 684 deaths (about 1\%). 


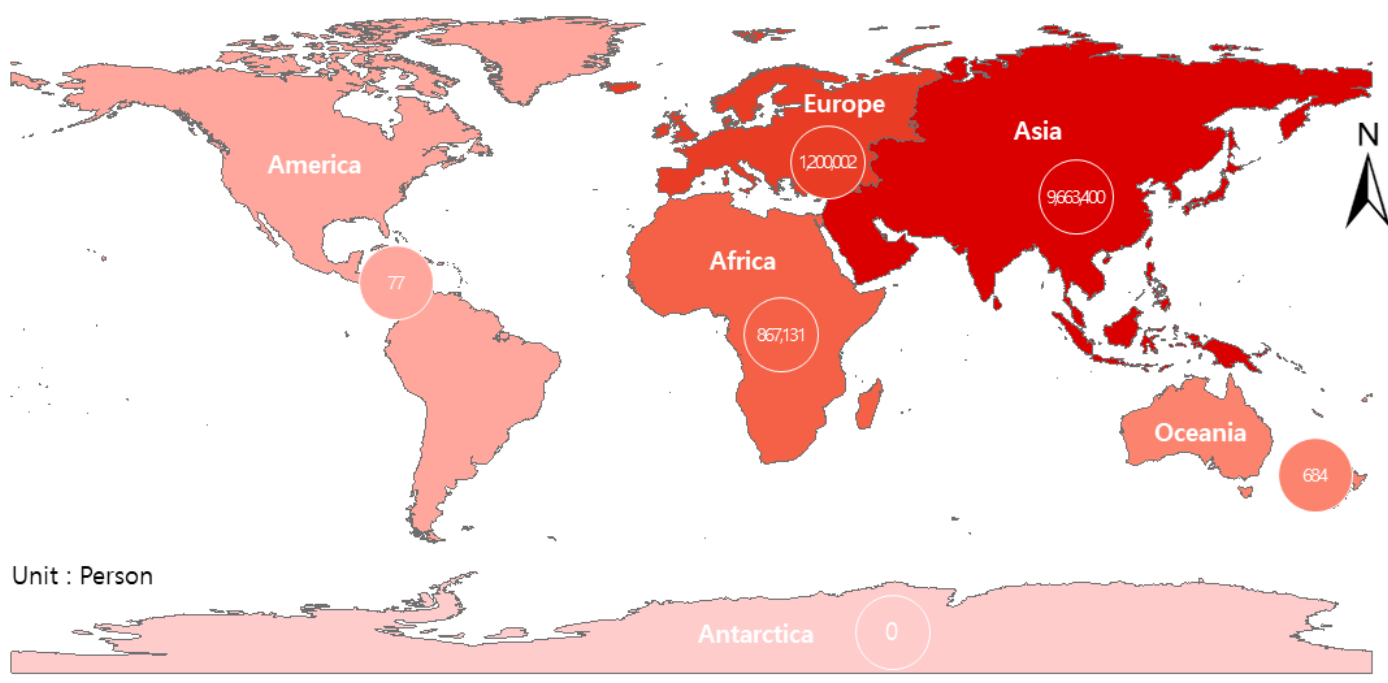

Figure 5. Characteristics of drought human losses by continent (1900-2018).

Table 2. Status of global drought human losses by year and by continent.

\begin{tabular}{cccccccc}
\hline \multirow{2}{*}{ Year } & \multicolumn{7}{c}{ Drought Human Losses (Person) } \\
\cline { 2 - 7 } & Asia & Americas & Europe & Africa & Oceania & South Pole & Sum \\
\hline $1900-1910$ & $1,250,000$ & - & - & 28,000 & - & - & $1,278,000$ \\
$1911-1920$ & 500,000 & - & - & 92,000 & - & - & 592,000 \\
$1921-1930$ & $3,000,000$ & - & $1,200,000$ & - & - & - & $4,200,000$ \\
$1931-1940$ & - & - & - & 4000 & - & - & 4000 \\
$1941-1950$ & $3,400,000$ & - & - & 46,000 & - & - & $3,446,000$ \\
$1951-1960$ & - & - & - & - & - & - & - \\
$1961-1970$ & $1,508,000$ & - & - & 2050 & 600 & - & $1,510,650$ \\
$1971-1980$ & 81 & - & - & 119,000 & - & - & 119,081 \\
$1981-1990$ & 2294 & 20 & 0 & 554,874 & - & - & 557,188 \\
$1991-2000$ & 2758 & 6 & 2 & 224 & 60 & - & 3050 \\
$2001-2010$ & 256 & 51 & - & 10,983 & - & - & 11,290 \\
$2011-2018$ & 11 & - & - & 10,000 & 24 & - & 10,035 \\
\hline Sum & $9,663,400$ & 77 & $1,200,002$ & 867,131 & 684 & - & $11,731,294$ \\
\hline
\end{tabular}

\subsection{Characteristics of Drought Damage Costs}

The total accumulated damage costs caused by global droughts from 1965 to 2018 were estimated at $\$ 17,367,007,000$. Among 146 countries that experienced more than one drought, 84 experienced the occurrence of damage costs (Figure 6). As there were no surveyed data or records available on damage costs between 1900 and 1964, the amount of damage costs was calculated using data on the damage costs from 1965 to 2018. The mean annual damage costs have continued to increase from approximately $\$ 140,000,000$ before 1970 to $\$ 670,000,000$ in $1980, \$ 2,007,000,000$ in $1990, \$ 3,810,000,000$ in $2000, \$ 2,520,000,000$ in 2010 , and $\$ 9,430,000,000$ in 2018. In the box-plot distribution of damage costs, the first quartile ( $25 \%$ ) was set at $\$ 250,041,000$, the second quartile (median) was set at $\$ 11,469,329,000$, and the third quartile $(75 \%)$ was set at $\$ 3,375,333,000$. The mean annual amount of damage costs from 1965 to 2018 was estimated at approximately $\$ 3,217,000,000$, with a range from a minimum of $\$ 21,000,000$ per year to a maximum of $\$ 24,751,200,000$ per year. 


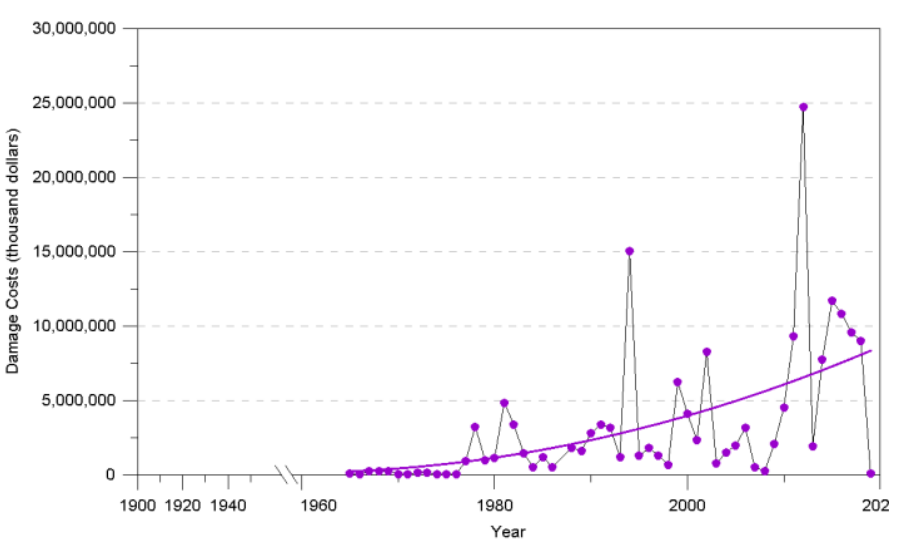

(a)

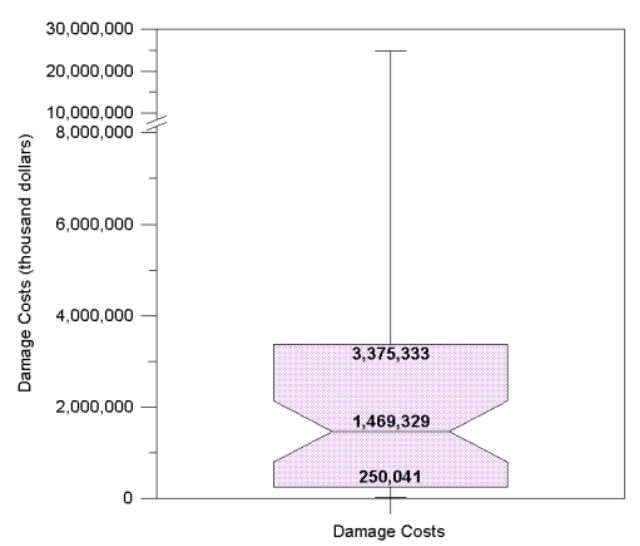

(b)

Figure 6. Characteristics of damage costs of global droughts: (a) drought damage costs by year, (b) distribution of drought damage costs.

In total, 84 countries experienced the occurrence of damage costs from 1965 to 2018. Divided by continent, 22 countries in the Americas experienced damage costs, while there were 21 countries in Africa, 21 countries in Asia, 15 countries in Europe, and 5 countries in Oceania (Figure 7). In terms of damage costs by continent, the Americas suffered damage costs worth $\$ 69,960,808,000$, and the most affected country in the continents was the United States, with damage costs worth $\$ 44,835,000,000$. Africa suffered damage costs worth $\$ 6,438,593,000$, and the most affected country in the continent was the Republic of South Africa, with damage costs worth $\$ 2,450,000,000$. Asia suffered damage costs worth $\$ 56,698,464,000$, and the most affected country in the continent was China, with damage costs worth $\$ 35,346,420,000$. Europe suffered damage costs worth $\$ 27,781,309,000$, and the most affected country in the continent was Spain, with damage costs worth $\$ 10,660,000,000$. Oceania suffered damage costs worth $\$ 12,790,900,000$, and the most affected country in the continent was Australia, with damage costs worth $\$ 11,773,000,000$. The amounts of drought-inflicted damage costs by continent and by country are presented in Table A1.

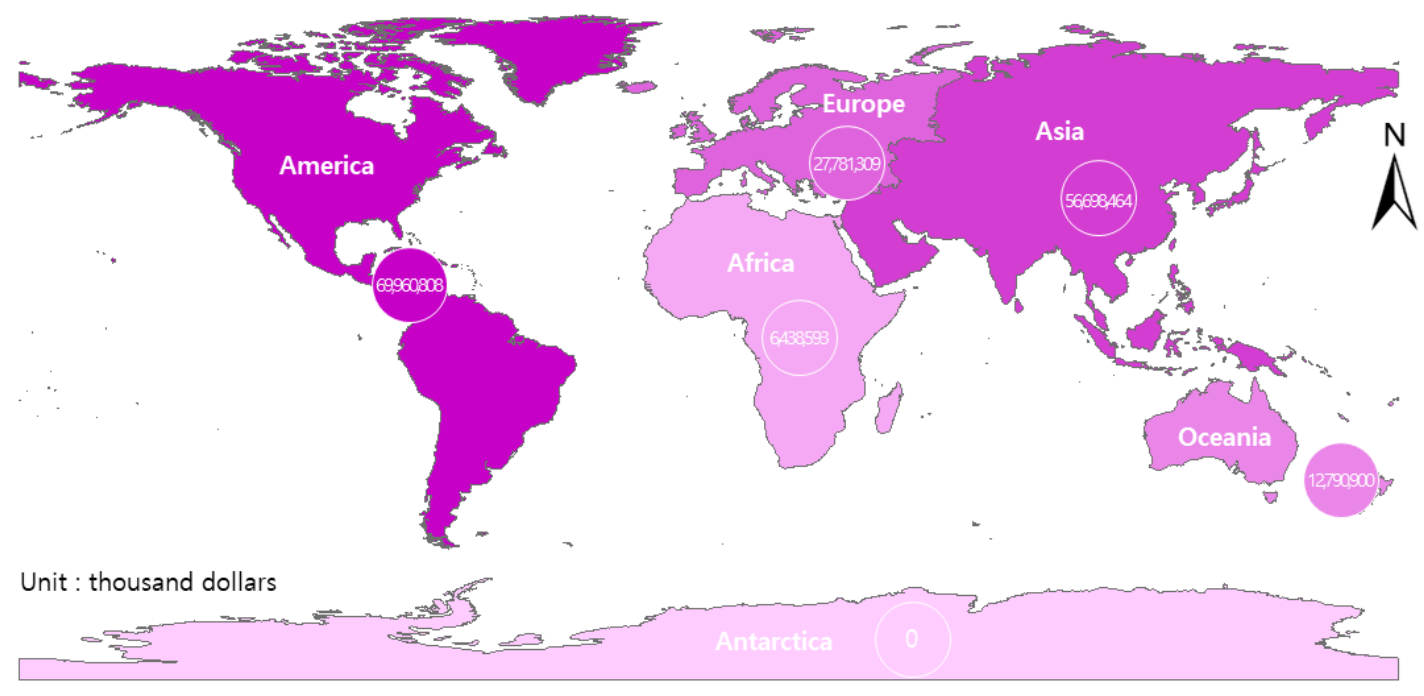

Figure 7. Characteristics of drought damage costs (1965 2018).

Global drought-induced damage costs have continued to increase at a steady pace at intervals of 10 years since 1965, and the total accumulated damage costs until 2018 amount to $\$ 173,670,074,000$ (Table 3). Based on damage costs worth $\$ 838,301,000$ for the period from 1961 to 1970, the damage costs at intervals of 10 years have increased approximately 21 times between 1981 and 1990, 45 times 
between 1991 and 2000, 30 times between 2001 and 2010, and 101 times between 2011 and 2018. This is attributable not only to urban development driven by industrial revolution but also to climate change, as both factors have made contributions to the recent increase in the frequency of drought damages, which has mutually led to a surge in damage costs. In terms of the characteristics of damage costs by continent, Africa suffered damage costs worth $\$ 6,438,593,000$ (approximately 3.7\%), Asia suffered damage costs worth $\$ 56,698,464,000$ (approximately 32.6\%), Europe suffered damage costs worth $\$ 27,781,309,000$ (approximately $16.0 \%$ ), the Americas suffered damage costs worth $\$ 69,960,808,000$ (approximately $40.3 \%$ ), and Oceania suffered damage costs worth $\$ 12,790,900,000$ (approximately 7.4\%).

Table 3. Status of global drought damage costs by year and by continent.

\begin{tabular}{cccccccc}
\hline \multirow{2}{*}{ Year } & \multicolumn{7}{c}{ Drought Damage Costs (Thousand US Dollars) } \\
\cline { 2 - 8 } & Asia & Americas & Europe & Africa & Oceania & South Pole & Sum \\
\hline $1900-1960$ & - & - & - & - & - & - & - \\
$1961-1970$ & 135,317 & 49,600 & - & 53,384 & 600,000 & - & 838,301 \\
$1971-1980$ & 385,201 & $5,329,000$ & 375,000 & 549,516 & - & - & $6,638,717$ \\
$1981-1990$ & 964,220 & $3,462,600$ & $7,530,000$ & 73,043 & $6,030,000$ & - & $18,059,863$ \\
$1991-2000$ & $18,990,798$ & $5,473,666$ & $9,616,600$ & $1,944,650$ & $2,073,000$ & - & $38,098,714$ \\
$2001-2010$ & $12,449,329$ & $6,496,273$ & $3,939,709$ & 300,000 & $2,000,000$ & - & $25,185,311$ \\
$2011-2018$ & $23,773,599$ & $49,149,669$ & $6,320,000$ & $3,518,000$ & $2,087,900$ & - & $84,849,168$ \\
\hline Sum & $56,698,464$ & $69,960,808$ & $27,781,309$ & $6,438,593$ & $12,790,900$ & - & $173,670,074$ \\
\hline
\end{tabular}

\section{Results}

\subsection{Establishment of Quantitative Standards on the Frequency of Drought Damages for Mega-Droughts}

This study investigated the frequency of drought damages from 1900 to 2018 by country. Regarding the frequency of drought damages by country, occurrences of drought damages were counted regardless of their duration, and the frequency of those drought damages per year was calculated by country. Drought continuous periods were calculated by the unit of year only, and it was found that droughts persisted for continuous periods ranging from 1 year to 17 years. The number of drought damages for continuous periods of more than one year between 1900 and 2018 was estimated to be 600 cases, with continuous periods of 1 to 7 years, 10 to 11 years, or up to 17 years (Figure 8).

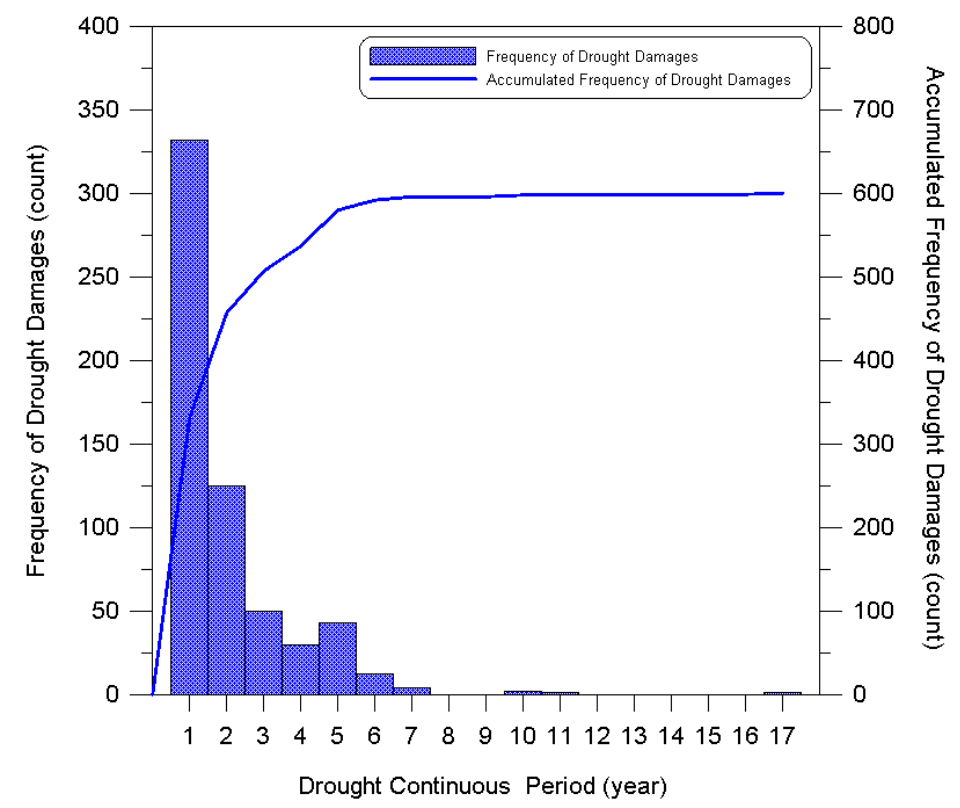

Figure 8. Characteristics of the frequency of drought damages considering continuous periods (1900-2018). 
When the frequency of drought damages was estimated in consideration of continuous periods, the number of drought damages was estimated at 332 cases for a continuous period of 1 year, 125 cases for a continuous period of 2 years, 50 cases for a continuous period of 3 years, 30 cases for a continuous period of 4 years, 43 cases for a continuous period of 5 years, 12 cases for a continuous period of 6 years, 4 cases for a continuous period of 7 years, 2 cases for a continuous period of 10 years, and 1 case for a continuous period of 11 years, bringing the total to 600 cases (Table 4). Regarding the duration of global drought damages, the total number of drought damages for a continuous period of one year accounted for approximately $55 \%$ of the total cases, $21 \%$ occurred over a continuous period of two years, $8 \%$ occurred over a continuous period of three years, $5 \%$ occurred over a continuous period of four years, $7 \%$ occurred over a continuous period of five years, and $2 \%$ occurred over a continuous period of six years, meaning that approximately $99 \%$ of them persisted for continuous periods of fewer than six years. Approximately $1 \%$ of all drought damages around the world persisted for continuous periods of more than seven years: Burkina Faso, Djibouti, Mozambique, and Senegal experienced drought damages that persisted for a continuous period of 7 years, Canada and Chad experienced drought damages that persisted for a continuous period of 10 years, Zimbabwe experienced drought damages that persisted for a continuous period of 11 years, and Mauritania experienced drought damages that persisted for a continuous period of 17 years.

Table 4. Status of the frequency of global drought damages considering continuous periods (1900-2018).

\begin{tabular}{ccc}
\hline Drought Continuous Period (Year) & Frequency of Droughts (Count) & Percentage (\%) \\
\hline 1 & 332 & 55.3 \\
2 & 125 & 20.8 \\
3 & 50 & 8.3 \\
4 & 30 & 5.0 \\
5 & 43 & 7.2 \\
6 & 12 & 2.0 \\
7 & 4 & 0.7 \\
$8-9$ & - & - \\
10 & 2 & 0.3 \\
11 & 1 & 0.2 \\
$12-17$ & - & - \\
17 & 1 & 0.2 \\
\hline Sum & 600 & 100.0 \\
\hline
\end{tabular}

This study examined continuous periods of drought damages to establish quantitative standards for the frequency of drought occurrences for mega-droughts. Although many studies have proposed various definitions of mega-droughts, there has been no clear universal definition applicable to the entire world. Therefore, this study aimed to establish quantitative standards based on past cases of drought damages. A mega-drought is defined as an extreme drought that is expected to redefine standards for policies related to national operation and social systems. Therefore, this study aimed to define droughts with a duration ranked in the top $1 \%$ in terms of the frequency of drought damages as a standard for the extreme dry spells called mega-droughts during the past 119-year period. This study defined the frequency of drought damages that persisted for continuous periods of more than seven years as a standard for the frequency of drought damage for mega-droughts.

\subsection{Establishment of Quantitative Standards on Human Losses for Mega-Droughts}

Global drought human losses were estimated by calculating the death toll based on the analysis results of drought damages for continuous periods. This study calculated the number of human losses for each continuous period ranging from 1 to 17 years. The total accumulated human losses from 1900 to 2018 were estimated at 11,731,924 people over continuous periods of 1 to 7 years. There were no surveyed data available on human losses for continuous periods of 10, 11, and 17 years (Figure 9). 


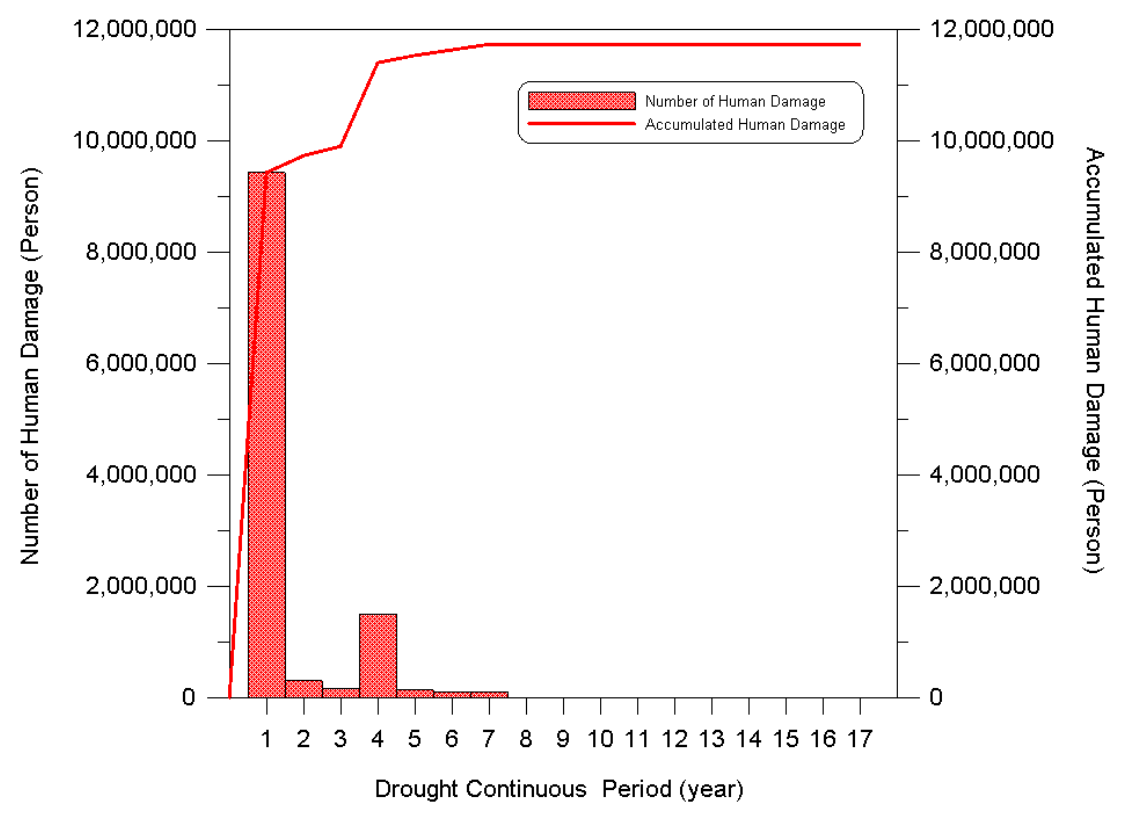

Figure 9. Characteristics of drought human damages considering continuous periods (1900-2018).

When human losses were estimated in consideration of continuous periods, the total death toll over a continuous period of one year was estimated at 9,429,343 people, with 301,409 deaths for a continuous period of two years, 169,788 deaths for a continuous period of three years, 1,500,132 deaths for a continuous period of four years, 130,537 deaths for a continuous period of five years, 100,085 deaths for a continuous period of six years, and 100,000 deaths for a continuous period of seven years. The total accumulated death toll for continuous periods of one to seven years was estimated at 11,731,924 people, with a mean annual death toll of 690,076 deaths (Table 5). When the frequency and continuous periods of droughts were taken into consideration, the mean annual death toll for continuous periods ranged from a minimum of 3263 deaths to a maximum of 304,172 deaths, with a mean annual death toll of 68,174 people. However, regarding the frequency of human losses, the total number of drought damages was estimated at 600 cases, but only 63 cases, or roughly $10 \%$, experienced the occurrence of drought human losses. The annual human losses were calculated based on the total of frequency and human losses for each country through continuous periods. Further, human losses were estimated only for continuous periods of 1 to 7 years, but there was no way to confirm human losses for longer continuous periods. In terms of human losses for continuous periods, China was the country with the highest death toll of 3,000,000 people for a continuous period of one year, Ethiopia was the highest with 3,000,000 deaths for a continuous period of two years, Sudan was the highest with 150,000 deaths for a continuous period of three years, Indonesia was the highest with 1,500,000 deaths for a continuous period of four years, Niger was the highest with 85,000 deaths for a continuous period of five years, Ethiopia was the highest with 100,000 deaths for a continuous period of six years, and Mozambique was the highest with 100,000 deaths for a continuous period of seven years.

This study examined drought continuous periods to establish quantitative standards on drought human losses for mega-droughts. Due to a lack of data on drought human losses, 63 cases of drought damages were used to estimate human losses, frequency, and mean annual human losses. The mean annual death toll for continuous periods of more than seven years, which was considered the standard for the frequency of drought damages for mega-drought, was estimated at 14,286 deaths. However, most drought human losses occurred before 1990. Although approximately 10,000 people lost their lives after 1991, most of these losses took place in Africa. In addition, given that drought human losses are being reduced by each country's disaster reduction measures, the occurrence of even one human loss is considered to be serious. Therefore, in consideration of realistic applications, this study aimed to set the standard for human losses for mega-droughts based on prior available data on damage 
costs, and defined the standard for human losses for mega-droughts as the occurrence of human losses induced by droughts that persisted in a country for continuous periods of more than seven years.

Table 5. Status of global drought human losses considering continuous periods (1900-2018).

\begin{tabular}{cccc}
\hline $\begin{array}{c}\text { Drought Continuous } \\
\text { Period }\end{array}$ & $\begin{array}{c}\text { Human Losses } \\
\text { (Person) }\end{array}$ & $\begin{array}{c}\text { Frequency of Drought } \\
\text { Damages (Count) }\end{array}$ & $\begin{array}{c}\text { Mean Annual Human } \\
\text { Losses (Person) }\end{array}$ \\
\hline 1 & $9,429,343$ & 31 & 304,172 \\
2 & 301,409 & 10 & 15,070 \\
3 & 169,788 & 8 & 7075 \\
4 & $1,500,132$ & 3 & 125,011 \\
5 & 130,537 & 8 & 3263 \\
6 & 100,085 & 2 & 8340 \\
7 & 100,000 & 1 & 14,286 \\
$8-17$ & - & - & - \\
\hline Sum & $11,731,294$ & 63 & 477,217 \\
\hline Mean & 690,076 & 9 & 68,174 \\
\hline
\end{tabular}

\subsection{Establishment of Quantitative Standards on Damage Costs for Mega-Droughts}

In terms of global drought damage costs by country, the sum of damage costs was calculated based on the analysis results of drought continuous periods. Regarding damage costs, they were estimated for continuous periods ranging from 1 to 17 years. The total drought damage costs accumulated from 1965 to 2018 amounted to $\$ 17,367,007,000$, with continuous periods ranging from 1 to 17 years. In the case of drought-induced damage costs, at least one case of damage costs occurred over continuous periods (Figure 10).

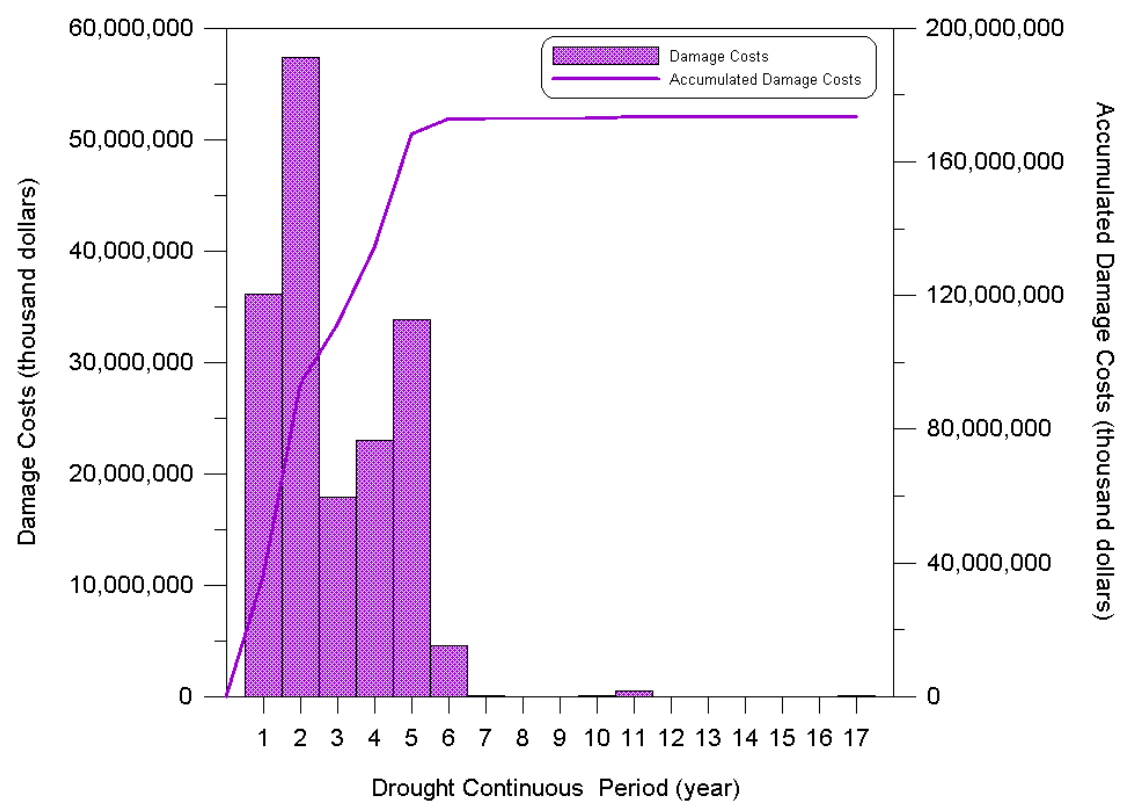

Figure 10. Characteristics of damage costs considering continuous periods (1965-2018).

When drought damage costs were estimated in consideration of continuous periods, the annual damage costs for a continuous period of 1 year were estimated at $\$ 36,151,790,000$, the annual damage costs for a continuous period of 2 years were estimated at $\$ 57,396,804,000$, the annual damage costs for a continuous period of 3 years were estimated at $\$ 17,906,726,000$, the annual damage costs for a continuous period of 4 years were estimated at $\$ 23,039,600,000$, the annual damage costs for a continuous period of 5 years were estimated at $\$ 33,880,115,000$, the annual damage costs for a continuous period 
of 6 years were estimated at $\$ 4,577,739,000$, the annual damage costs for a continuous period of 7 years were estimated at $\$ 74,800,000$, the annual damage costs for a continuous period of 10 years were estimated at $\$ 83,000,000$, the annual damage costs for a continuous period of 11 years were estimated at $\$ 500,000,000$, and the annual damage costs for a continuous period of 17 years were estimated at $\$ 59,500,000$. The total accumulated damage costs throughout all continuous periods amounted to $\$ 173,670,074,000$, with the mean annual damage costs totaling $\$ 17,367,007,000$ (Table 6). The mean annual damage costs in consideration of continuous periods and the frequency of damage costs ranged from a minimum of $\$ 3,500,000$ to a maximum of $\$ 677,602,000$, with the mean damage costs being $\$ 302,069,000$. However, regarding the frequency of damage costs among all 600 cases of drought damages, 181 (approximately 30\%) experienced the occurrence of damage costs. In addition, as data on damage costs only began to be recorded after 1965, it was impossible to estimate drought damage costs before 1965. In terms of countries with the greatest damage costs by each continuous period, Argentina suffered the most severe damage costs of $\$ 3,400,000,000$ for a continuous period of 1 year, the United States suffered the highest damage costs of $\$ 28,000,000,000$ for a continuous period of 2 years, Vietnam suffered the highest damage costs of $\$ 6,750,000,000$ for a continuous period of 3 years, China suffered the highest damage costs of $\$ 6,204,000,000$ for a continuous period of 4 years, China suffered the highest damage costs of $\$ 13,821,200,000$ for a continuous period of 5 years, Spain suffered the highest damage costs of $\$ 4,500,000,000$ for a continuous period of 6 years, Senegal suffered the highest damage costs of $\$ 74,800,000$ for a continuous period of 7 years, Chad suffered the highest damage costs of $\$ 83,000,000$ for a continuous period of 10 years, Zimbabwe suffered the highest damage costs of $\$ 500,000,000$ for a continuous period of 11 years, and Mauritania suffered the highest damage costs of $\$ 59,500,000$ for a continuous period of 17 years.

Table 6. Status of global drought damage costs considering continuous periods (1965-2018).

\begin{tabular}{cccc}
\hline $\begin{array}{c}\text { Drought Continuous Period } \\
(\mathbf{y r})\end{array}$ & $\begin{array}{c}\text { Damage Costs } \\
\text { (Thousand US Dollars) }\end{array}$ & $\begin{array}{c}\text { Frequency of Drought } \\
\text { Damages (Count) }\end{array}$ & $\begin{array}{c}\text { Mean Annual Damage Costs } \\
\text { (Thousand US Dollars) }\end{array}$ \\
\hline 1 & $36,151,790$ & 98 & 368,896 \\
2 & $57,396,804$ & 34 & 844,071 \\
3 & $17,906,726$ & 21 & 284,234 \\
4 & $23,039,600$ & 11 & 523,627 \\
5 & $33,880,115$ & 10 & 677,602 \\
6 & $4,577,739$ & 3 & 254,319 \\
7 & 74,800 & 1 & 10,686 \\
$8-9$ & - & - & - \\
10 & 83,000 & 1 & 8300 \\
11 & 500,000 & 1 & 45,455 \\
$12-16$ & - & - & - \\
17 & 59,500 & 1 & 3500 \\
\hline Sum & $173,670,074$ & 181 & $3,020,690$ \\
\hline Mean (Total) & $17,367,007$ & 18 & 302,069 \\
\hline Mean (more than seven years) & 179,325 & 1 & 16,985 \\
\hline
\end{tabular}

This study examined drought continuous periods to set quantitative standards for the level of damage costs for mega-droughts. As there were no data on damage costs available before 1965, data on 181 cases of drought damages after 1965 were used to estimate damage costs by year, frequency, and mean annual damage costs. The mean annual damage costs in consideration of continuous periods were estimated to total $\$ 17,367,007,000$, whereas the mean annual damage costs in reflection of the frequency of drought damages and continuous periods were estimated to total $\$ 302,069,000$. The measure of mean annual damage costs over continuous periods of more than seven years, which was adopted as the standard for the frequency of drought damages for mega-droughts, was estimated to be approximately $\$ 17,000,000$. The amount of damage costs increased exponentially by more than two times at intervals of 10 years after 1961. In addition, due to the influence of urban development and climate change, the amount of damage costs occurring between 2011 and 2018 accounted for 
nearly $50 \%$ of the total accumulated damage costs. After reviewing the past data on damage costs, it was found that drought damage costs were likely to increase at a steady pace. It should be noted that the study defined the mean annual damage costs induced by droughts that persisted for more than seven years as the standard for damage costs for mega-droughts in the same way as the standard for the frequency of drought damages. Therefore, in consideration of realistic applications, this study aimed to set the standard for damage costs for mega-droughts based on the past data on damage costs, and defined the standard for damage costs for mega-droughts as mean annual damage costs worth $\$ 17,000,000$, induced by droughts that persisted in a country for continuous periods of more than seven years.

\section{Discussion}

This study aimed to set the definition for quantitative standards for mega-droughts using data on global drought damages. Firstly, data on drought damages by year and by continent were surveyed to identify the characteristics of the frequency of drought damages, human losses, and damage costs. Secondly, drought continuous periods by country were taken into consideration to define quantitative standards for the frequency of drought damages, human losses, and damage costs for mega-droughts.

Recent studies on mega-droughts have defined certain droughts that occurred in the western coast of the U.S., Colorado, Northwest America, Chile, and Southwest Europe for continuous periods of more than five years or decades as mega-droughts [22,33]. The existing studies usually targeted one country to examine the severity of drought damages and used indexes to define mega-droughts by analyzing those drought damages that persisted for several years. This means that the impact of drought damages perceived by each country was not evaluated based on universal standards, but rather that different drought evaluation indexes were developed based on drought damages that persisted for several years. The biggest drought damage on the continent from 1900 to 2018, the frequency of drought damages occurred 673 cases in Africa, drought human losses occurred 9,663,400 deaths in Asia, and drought damage costs occurred $\$ 69,960,808,000$ in Americas.

Some studies analyzing the paleoclimatic impact of droughts found evidence to support that damages caused by prolonged droughts with continuous periods of 10 years had occurred periodically in the past $[1,19,27-29]$. In recognition of the severity of drought problems, existing studies on mega-droughts have stressed the need for alternative measures to reduce occurrences of disasters and their corresponding damages. The prolonged occurrence of extreme droughts is perceived as a natural disaster that requires an appropriate measure to reduce possible damages through national disaster management. If it constitutes a drought by hydrological impact, but the subsequent damages are reduced through national disaster management, it is hard to define these as drought damages.

Therefore, this study aimed to establish quantitative standards for mega-droughts by examining past occurrences of drought damages and proposing universal standards applicable to the entire world. Of course, common factors associated with drought damages occurring in all countries have not always been included in analyses of data on global drought damages. Because the characteristics of countries and continents are different, even if drought damages of the same condition are different, there is a limit to obtaining homogeneous data for many years. To overcome such data limitations, this study set standards for mega-droughts which can be universally applied to the entire world in consideration of the general characteristics of damage factors and through drought duration analyses.

Recent worldwide occurrences of droughts and heat waves due to climate change have contributed to increased variability in recent precipitation and have also brought about direct and indirect damages to agriculture and industry. Many studies have been conducted in attempts to predict the occurrence of drought damages resulting from climate change in the future using such indexes as Standardized Precipitation Index (SPI), PDSI, and DSI, and these have predicted that severe dry spells equivalent to mega-droughts are likely to occur periodically until 2100 [36-42]. If the standards for mega-droughts proposed by this study are applied as the criteria through which to evaluate mega-droughts, they can enable each country to develop proactive responses to mega-droughts resulting from climate change. 
The assessment of droughts typically uses a lot of meteorological and hydrologic indices. However, there is a limit to the wide range of applications to present integrated standards considering various meteorological and hydrological indices around the world. Although this study had some limitations due to the absence of a clear definition of drought evaluation indexes for mega-droughts, the study results are expected to be useful in the development of long-term measures to prevent disasters.

\section{Conclusions}

This study aimed to set quantitative standards by which to determine the magnitude of drought damages required to constitute mega-droughts using data on global drought damages from 1900 to 2018. This study used data on drought damages around the world collected and managed by EM-DAT and operated by CRED. The countries with the most drought damage in each continent are Mauritania in Africa, Brazil in the Americas, China in Asia, Spain in Europe, and Australia in Oceania.

Among the general characteristics of drought damages, the frequency of drought damages and damage costs have been increasing at a steady pace from 1900 to 2018, with a mean annual number of 11 drought damages and mean annual damage costs of approximately $\$ 3,217,000,000$. In the meantime, human losses have continued to decline year by year, with a mean annual count of approximately 213,000 human deaths. Regarding the characteristics of drought damages by continent, Africa was ranked no. 1 in the frequency of drought damages, Asia was ranked no. 1 in human losses, and the Americas were ranked no. 1 in damage costs.

This study examined the frequency of drought damages, human losses, and damage costs in each continuous period in order to set quantitative standards for mega-droughts. Those drought damages occurring around the world from 1900 to 2018 had continuous periods ranging from a minimum of 1 year to a maximum of 17 years. The total frequency of drought damages was estimated at 600 cases. Among them, a total of 63 involved human losses, with a total death toll of 11,731,294 people, a total of 181 cases involving damage costs, and a total of $\$ 173,670,074,000$ in damage costs. There were no available surveyed data on human losses in the cases of continuous periods of 10,11, and 17 years. In the case of damage costs, there were no surveyed or confirmed data on drought damage costs before 1965.

This study used data on global droughts to compare human losses and damage costs based on the frequency of drought damages and then set quantitative standards by which to determine the frequency of drought damages required to constitute a mega-drought. The frequency of drought damages was estimated using more than 119 years' worth of drought data, and the frequency of drought damages ranked in the top $1 \%$ was set as the standard for a mega-drought. Therefore, regarding the criterion for the frequency of drought damages, those droughts which persisted in a country for continuous periods of seven years or more and which belonged to the top $1 \%$ of all drought continuous periods were considered to constitute mega-droughts.

In terms of the frequency of drought human losses, since only 63 cases, or $10 \%$ of all droughts considered, involved the occurrence of human losses, this made it difficult to set a quantitative definition for mega-droughts through data analysis. However, drought human losses have continued to decline from 1900 to 2018, and recent national disaster management strategies have two top priorities: one is the reduction in human losses and the other is disaster reduction. Therefore, this study set those droughts with human losses which persisted for a continuous period of seven years or more as a standard by which to determine the magnitude of human losses required to constitute a mega-drought.

Data on drought damage costs started to be recorded after 1965, and the magnitude of damage costs since then has increased by approximately two times. In addition, drought damages are expected to continue to increase due to rising temperatures and irregular precipitation patterns resulting from recent climate change. This study set the mean annual damage costs caused by droughts with continuous periods of seven years of more as a standard by which to determine the magnitude of damage costs required to constitute a mega-drought. As a result, a drought with a continuous period 
of seven years or more and with mean annual damage costs of $\$ 17,000,000$ was set as the condition required to constitute a mega-drought.

Therefore, this study set the standards for mega-drought as follows: (1) if drought damages continue to occur in a country for more than seven years, (2) if human losses continue to occur in a country for more than seven years, and (3) if mean annual damage costs of $\$ 17,000,000$ continue to occur in a country for more than seven years. The definition of a mega-drought proposed by this study was set based on past data on drought damages around the world. As the quantitative standards for mega-droughts were established based on drought damage data regardless of the land sizes or GDP levels of the countries involved, this definition has some limitations. However, the research findings of this study are expected to be useful as basic data with which to develop a national disaster management framework for drought preparedness or reduction measures.

Author Contributions: Conceptualization, Y.S. and M.J.; methodology, M.J.; validation, Y.S. and M.J.; formal analysis: Y.S.; resources, Y.S.; data curation, Y.S.; writing-original draft preparation, Y.S.; writing-review and editing, M.J.; visualization, Y.S.; supervision, M.J.; project administration, M.J. All authors have read and agreed to the published version of the manuscript.

Funding: This research was funded by Korean Ministry of Interior and Safety grant number 2019-MOIS31-010 and the APC was funded by Korean Ministry of Interior and Safety.

Acknowledgments: This research was supported by a grant (2019-MOIS31-010) from Fundamental Technology Development Program for Extreme Disaster Response funded by Korean Ministry of Interior and Safety (MOIS).

Conflicts of Interest: The authors declare no conflict of interest.

\section{Appendix A}

Table A1. Classification of drought damages by continent and by country (1900-2018).

\begin{tabular}{|c|c|c|c|c|}
\hline Continent & Country & $\begin{array}{c}\text { Frequency of } \\
\text { Drought Damages } \\
\text { (Count) }\end{array}$ & $\begin{array}{l}\text { Human Losses } \\
\text { (Person) }\end{array}$ & $\begin{array}{c}\text { Damage Costs } \\
\text { (Thousand US } \\
\text { Dollars) }\end{array}$ \\
\hline \multirow{25}{*}{ Africa } & Algeria & 3 & 0 & 0 \\
\hline & Angola & 14 & 58 & 0 \\
\hline & Benin & 7 & 0 & 651 \\
\hline & Botswana & 11 & 0 & 47,000 \\
\hline & Burkina Faso & 35 & 0 & 0 \\
\hline & Burundi & 11 & 126 & 0 \\
\hline & Côte d'Ivoire & 1 & 0 & 0 \\
\hline & Cabo Verde & 24 & 85,000 & 0 \\
\hline & Cameroon & 6 & 0 & 1500 \\
\hline & Central African Republic & 2 & 0 & 0 \\
\hline & Chad & 34 & 3,000 & 83,000 \\
\hline & Comoros & 1 & 0 & 0 \\
\hline & $\begin{array}{l}\text { Democratic Republic of } \\
\text { Congo }\end{array}$ & 3 & 0 & 0 \\
\hline & Congo & 1 & 0 & 0 \\
\hline & Djibouti & 13 & 0 & 0 \\
\hline & Eritrea & 7 & 0 & 0 \\
\hline & Ethiopia & 33 & 402,367 & $1,492,600$ \\
\hline & Gambia & 27 & 0 & 700 \\
\hline & Ghana & 5 & 0 & 100 \\
\hline & Guinea & 4 & 12 & 0 \\
\hline & Guinea-Bissau & 20 & 0 & 0 \\
\hline & Kenya & 27 & 196 & 1500 \\
\hline & Lesotho & 14 & 0 & 1000 \\
\hline & Liberia & 1 & 0 & 0 \\
\hline & Madagascar & 21 & 200 & 0 \\
\hline
\end{tabular}


Table A1. Cont.

\begin{tabular}{|c|c|c|c|c|}
\hline Continent & Country & $\begin{array}{c}\text { Frequency of } \\
\text { Drought Damages } \\
\text { (Count) }\end{array}$ & $\begin{array}{l}\text { Human Losses } \\
\text { (Person) }\end{array}$ & $\begin{array}{c}\text { Damage Costs } \\
\text { (Thousand US } \\
\text { Dollars) }\end{array}$ \\
\hline & Malawi & 16 & 500 & 0 \\
\hline & Mali & 25 & 0 & 0 \\
\hline & Mauritania & 39 & 0 & 59,500 \\
\hline & Mauritius & 1 & 0 & 175,000 \\
\hline & Morocco & 7 & 0 & 900,100 \\
\hline & Mozambique & 23 & 100,068 & 50,000 \\
\hline & Namibia & 16 & 0 & 175,000 \\
\hline & Niger & 37 & 85,000 & 0 \\
\hline & Nigeria & 3 & 0 & 71,103 \\
\hline & Rwanda & 13 & 237 & 0 \\
\hline & Sao Tome and Principe & 3 & 0 & 0 \\
\hline & Senegal & 33 & 0 & 374,800 \\
\hline & Somalia & 22 & 39,673 & 0 \\
\hline & South Africa & 14 & 0 & $2,450,000$ \\
\hline & South Sudan & 3 & 0 & 0 \\
\hline & Sudan & 13 & 150,000 & 0 \\
\hline & Swaziland & 15 & 500 & 1739 \\
\hline & Tanzania, United Republic of & 16 & 0 & 0 \\
\hline & Togo & 3 & 0 & 500 \\
\hline & Tunisia & 2 & 0 & 0 \\
\hline & Uganda & 15 & 194 & 1800 \\
\hline & Zambia & 6 & 0 & 0 \\
\hline & Zimbabwe & 23 & 0 & 551,000 \\
\hline \multirow{30}{*}{ Americas } & Anguilla & 5 & 0 & 0 \\
\hline & Antigua and Barbuda & 1 & 0 & 0 \\
\hline & Argentina & 3 & 0 & $3,520,000$ \\
\hline & Barbados & 1 & 0 & 0 \\
\hline & Bolivia (Plurinational State of) & 14 & 0 & $1,515,600$ \\
\hline & Brazil & 22 & 20 & $11,183,100$ \\
\hline & Canada & 18 & 0 & $4,810,000$ \\
\hline & Chile & 6 & 0 & 255,000 \\
\hline & Colombia & 3 & 0 & 0 \\
\hline & Costa Rica & 4 & 0 & 24,000 \\
\hline & Cuba & 10 & 0 & 183,139 \\
\hline & Dominican Republic (the) & 1 & 0 & 5000 \\
\hline & Ecuador & 5 & 0 & 1700 \\
\hline & El Salvador & 9 & 0 & 357,400 \\
\hline & Grenada & 1 & 0 & 0 \\
\hline & Guatemala & 11 & 41 & 168,669 \\
\hline & Guyana & 4 & 0 & 43,700 \\
\hline & Haiti & 15 & 0 & 87,000 \\
\hline & Honduras & 18 & 0 & 17,000 \\
\hline & Jamaica & 6 & 0 & 6500 \\
\hline & Mexico & 8 & 0 & $1,610,000$ \\
\hline & Nicaragua & 8 & 0 & 18,000 \\
\hline & Panama & 5 & 0 & 272,000 \\
\hline & Paraguay & 14 & 16 & 0 \\
\hline & Peru & 8 & 0 & 296,000 \\
\hline & Puerto Rico & 1 & 0 & 2000 \\
\hline & Saint Lucia & 1 & 0 & 0 \\
\hline & $\begin{array}{c}\text { Saint Vincent and the } \\
\text { Grenadines }\end{array}$ & 1 & 0 & 0 \\
\hline & Trinidad and Tobago & 1 & 0 & 0 \\
\hline & United States of America & 20 & 0 & $44,835,000$ \\
\hline
\end{tabular}


Table A1. Cont.

\begin{tabular}{|c|c|c|c|c|}
\hline Continent & Country & $\begin{array}{c}\text { Frequency of } \\
\text { Drought Damages } \\
\text { (Count) }\end{array}$ & $\begin{array}{l}\text { Human Losses } \\
\text { (Person) }\end{array}$ & $\begin{array}{c}\text { Damage Costs } \\
\text { (Thousand US } \\
\text { Dollars) }\end{array}$ \\
\hline & Uruguay & 3 & 0 & 750,000 \\
\hline & Republic of Venezuela & 2 & 0 & 0 \\
\hline \multirow{34}{*}{ Asia } & Afghanistan & 11 & 37 & 142,250 \\
\hline & Armenia & 1 & 0 & 100,000 \\
\hline & Azerbaijan & 1 & 0 & 100,000 \\
\hline & Bangladesh & 7 & $1,900,018$ & 0 \\
\hline & Cambodia & 8 & 0 & 138,000 \\
\hline & China & 34 & $3,503,534$ & $35,346,420$ \\
\hline & Cyprus & 2 & 0 & 0 \\
\hline & Georgia & 2 & 0 & 200,000 \\
\hline & Hong Kong & 7 & 0 & 0 \\
\hline & India & 20 & $4,250,320$ & $5,441,122$ \\
\hline & Indonesia & 11 & 9340 & 160,200 \\
\hline & Iran (Islamic Republic of) & 4 & 0 & $3,300,000$ \\
\hline & Iraq & 7 & 0 & 2,000 \\
\hline & Israel & 1 & 0 & 75,000 \\
\hline & Japan & 1 & 0 & 0 \\
\hline & Jordan & 2 & 0 & 0 \\
\hline & $\begin{array}{l}\text { Democratic People's } \\
\text { Republic Of Korea }\end{array}$ & 3 & 0 & 0 \\
\hline & Republic of Korea & 3 & 0 & 0 \\
\hline & Kyrgyzstan & 1 & 0 & 0 \\
\hline & $\begin{array}{c}\text { Lao People's Democratic } \\
\text { Republic }\end{array}$ & 7 & 0 & 1000 \\
\hline & Malaysia & 2 & 0 & 0 \\
\hline & Mongolia & 3 & 0 & 0 \\
\hline & Nepal & 8 & 0 & 10,000 \\
\hline & Pakistan & 5 & 143 & 247,000 \\
\hline & Philippines & 12 & 8 & 148,852 \\
\hline & Sri Lanka & 15 & 0 & 45,000 \\
\hline & Syrian Arab Republic & 5 & 0 & 0 \\
\hline & Tajikistan & 3 & 0 & 57,000 \\
\hline & Thailand & 13 & 0 & $3,725,500$ \\
\hline & Timor-Leste & 2 & 0 & 0 \\
\hline & Uzbekistan & 2 & 0 & 50,000 \\
\hline & Viet Nam & 9 & 0 & $7,399,120$ \\
\hline & Yemen Arab Rep & 4 & 0 & 10,000 \\
\hline & Yemen P Dem Rep & 2 & 0 & 0 \\
\hline \multirow{13}{*}{ Europe } & Albania & 3 & 0 & 0 \\
\hline & Belgium & 1 & 0 & 0 \\
\hline & Bosnia and Herzegovina & 2 & 0 & 298,000 \\
\hline & Bulgaria & 3 & 0 & 0 \\
\hline & Croatia & 1 & 0 & 330,000 \\
\hline & Denmark & 1 & 0 & 751,700 \\
\hline & France & 4 & 0 & $1,610,000$ \\
\hline & Greece & 1 & 0 & $1,000,000$ \\
\hline & Hungary & 3 & 0 & 984,000 \\
\hline & Italy & 4 & 0 & $4,290,000$ \\
\hline & Lithuania & 3 & 0 & 278,473 \\
\hline & Macedonia & 1 & 0 & 0 \\
\hline & Moldova & 3 & 2 & 406,000 \\
\hline
\end{tabular}


Table A1. Cont.

\begin{tabular}{|c|c|c|c|c|}
\hline Continent & Country & $\begin{array}{c}\text { Frequency of } \\
\text { Drought Damages } \\
\text { (Count) }\end{array}$ & $\begin{array}{l}\text { Human Losses } \\
\text { (Person) }\end{array}$ & $\begin{array}{c}\text { Damage Costs } \\
\text { (Thousand US } \\
\text { Dollars) }\end{array}$ \\
\hline & Poland & 1 & 0 & 0 \\
\hline & Portugal & 4 & 0 & $1,443,136$ \\
\hline & Romania & 2 & 0 & 500,000 \\
\hline & Russian Federation & 5 & 0 & $2,540,000$ \\
\hline & Soviet Union & 1 & $1,200,000$ & 0 \\
\hline & Spain & 11 & 0 & $10,660,000$ \\
\hline & Ukraine & 1 & 0 & $1,690,000$ \\
\hline & Yugoslavia & 1 & 0 & $1,000,000$ \\
\hline \multirow{11}{*}{ Oceania } & Australia & 17 & 600 & $11,773,000$ \\
\hline & Fiji & 3 & 0 & 30,000 \\
\hline & Kiribati & 1 & 0 & 0 \\
\hline & Marshall Islands & 3 & 0 & 4900 \\
\hline & $\begin{array}{c}\text { Micronesia (Federated } \\
\text { States of) }\end{array}$ & 2 & 0 & 0 \\
\hline & New Zealand & 2 & 0 & 923,000 \\
\hline & Papua New Guinea & 5 & 84 & 60,000 \\
\hline & Samoa & 1 & 0 & 0 \\
\hline & Solomon Islands & 3 & 0 & 0 \\
\hline & Tonga & 1 & 0 & 0 \\
\hline & Tuvalu & 1 & 0 & 0 \\
\hline
\end{tabular}

\section{References}

1. Cook, E.R.; Seager, R.; Heim, R.R.; Herweijer, C.; Vose, R.S.; Woodhouse, C. Megadroughts in North America: Placing IPCC projections of hydroclimatic change in a long-term palaeoclimate context. J. Quat. Sci. 2010, 25, 48-61. [CrossRef]

2. Mao, Y.; Nijssen, B.; Lettenmaier, D.P. Is climate change implicated in the 2013-2014 California drought? A hydrologic perspective. Geophys. Res. Lett. 2015, 42, 2805-2813. [CrossRef]

3. Cook, B.I.; Smerdon, J.E.; Seager, R.; Coats, S. Global warming and 21st century drying. Clim. Dyn. 2014, 43, 2607-2627. [CrossRef]

4. Delworth, T.L.; Zeng, F.; Rosati, A.; Vecchi, G.A.; Wittenberg, A.T. A link between the hiatus in global warming and North American drought. J. Clim. 2015, 28, 3834-3845. [CrossRef]

5. Diffenbaugh, N.S.; Swain, D.L.; Touma, D. Anthropogenic warming has increased drought risk in California. Proc. Natl. Acad. Sci. USA 2015, 112, 3931-3936. [CrossRef]

6. Mann, M.E.; Gleick, P.H. Climate change and California drought in the 21st century. Proc. Natl. Acad. Sci. USA 2015, 112, 3858-3859. [CrossRef]

7. Cheng, L.; Hoerling, M.; AghaKouchak, A.; Livneh, B.; Quan, X.-W.; Eischeid, J. How has human-induced climate change affected California drought risk? J. Clim. 2016, 29, 111-120. [CrossRef]

8. Hartmann, D.L. Pacific sea surface temperature and the winter of 2014. Geophys. Res. Lett. 2015, 42, 1894-1902. [CrossRef]

9. Seager, R.; Hoerling, M. Atmosphere and ocean origins of North American droughts*. J. Clim. 2014, 27, 4581-4606. [CrossRef]

10. Seager, R.; Hoerling, M.; Schubert, S.; Wang, H.; Lyon, B.; Kumar, A.; Nakamura, J.; Henderson, N.H. Causes and Predictability of the 2011-14 California Drought; assessment report; NOAA: Silver Spring, MD, USA, 2014.

11. Wang, S.Y.; Hipps, L.; Gillies, R.R.; Yoon, J.H. Probable causes of the abnormal ridge accompanying the 2013-2014 California drought: ENSO precursor and anthropogenic warming footprint. Geophys. Res. Lett. 2014, 41, 3220-3226. [CrossRef]

12. Williams, A.P.; Seager, R.; Abatzoglou, J.T.; Cook, B.I.; Smerdon, J.E.; Cook, E.R. Contribution of anthropogenic warming to California drought during 2012-2014. Geophys. Res. Lett. 2015, 42, 6819-6828. [CrossRef] 
13. Acuna-Soto, R.; Stahle, D.W.; Cleaveland, M.K.; Therrell, M.D. Megadrought and megadeath in 16th century Mexico. Emerg. Infect. Dis. 2002, 8, 360-362. [CrossRef] [PubMed]

14. Woodhouse, C.A.; Overpeck, J.T. 2000 years of drought variability in the central United States. Bull. Am. Meteorol. Soc. 1998, 79, 2693-2714. [CrossRef]

15. Buckley, B.M.; Anchukaitis, K.J.; Penny, D.; Fletcher, R.; Cook, E.R.; Sano, M.; Le, C.N.; Wichienkeeo, A.; Minh, T.T.; Hong, T.M. Climate as a contributing factor in the demise of Angkor, Cambodia. Proc. Natl. Acad. Sci. USA 2010, 107, 6748-6752. [CrossRef]

16. Shanahan, T.M.; Overpeck, J.T.; Anchukaitis, K.J.; Beck, J.W.; Cole, J.E.; Dettman, D.L.; Peck, J.A.; Scholz, C.A.; King, J.W. Atlantic forcing of persistent drought in West Africa. Science 2009, 324, 377-380. [CrossRef]

17. Benson, L.; Petersen, K.; Stein, J. Anasazi (pre-Columbian Native-American) migrations during the middle-12th and late-13th centuries-Were they drought induced? Clim. Chang. 2007, 83, 187-213. [CrossRef]

18. Hodell, D.A.; Curtis, J.H.; Brenner, M. Possible role of climate in the collapse of Classic Maya civilization. Nature 1995, 375, 391-394. [CrossRef]

19. Cook, B.I.; Ault, T.R.; Smerdon, J.E. Unprecedented 21st century drought risk in the American Southwest and Central Plains. Sci. Adv. 2015, 1, e1400082. [CrossRef]

20. Ault, T.R.; Cole, J.E.; Overpeck, J.T.; Pederson, G.T.; Meko, D.M. Assessing the risk of persistent drought using climate model simulations and paleoclimate data. J. Clim. 2014, 27, 7529-7549. [CrossRef]

21. Swain, D.; Tsiang, M.; Haugen, M.; Singh, D.; Charland, A.; Rajaratnam, B.; Diffenbaugh, N. The extraordinary California drought of 2013/2014: Character, context, and the role of climate change. Bull. Am. Meteorol. Soc. 2014, 95, S3-S7.

22. Kogan, F.; Guo, W. 2006-2015 mega-drought in the western USA and its monitoring from space data. J. Geomat. Nat. Hazards Risk 2015, 6, 651-668. [CrossRef]

23. Cook, B.I.; Miller, R.L.; Seager, R. Amplification of the North American "Dust Bowl"drought through human-induced land degradation. Proc. Natl. Acad. Sci. USA 2009, 106, 4997-5001. [CrossRef] [PubMed]

24. Cook, B.I.; Seager, R.; Smerdon, J.E. The worst North American drought year of the last millennium: 1934. Geophys. Res. Lett. 2014, 41, 7298-7305. [CrossRef]

25. Seager, R.; Ting, M.; Held, I.; Kushnir, Y.; Lu, J.; Vecchi, G.; Huang, H.-P.; Harnik, N.; Leetmaa, A.; Lau, N.-C. Model projections of an imminent transition to a more arid climate in southwestern North America. Science 2007, 316, 1181-1184. [CrossRef]

26. Woodhouse, C.A.; Meko, D.M.; MacDonald, G.M.; Stahle, D.W.; Cook, E.R. A 1,200-year perspective of 21st century drought in southwestern North America. Proc. Natl. Acad. Sci. USA 2010, 107, 21283-21288. [CrossRef]

27. Griffin, D.; Anchukaitis, K.J. How unusual is the 2012-2014 California drought? Geophys. Res. Lett. 2014, 41, 9017-9023. [CrossRef]

28. MacDonald, G.M. Severe and sustained drought in southern California and the West: Present conditions and insights from the past on causes and impacts. Quat. Int. 2007, 173, 87-100. [CrossRef]

29. Schimmelmann, A.; Lange, C.B.; Meggers, B.J. Palaeoclimatic and archaeological evidence for a 200-yr recurrence of floods and droughts linking California, Mesoamerica and South America over the past 2000 years. Holocene 2003, 13, 763-778. [CrossRef]

30. Devineni, N.; Lall, U.; Etienne, E.; Shi, D.; Xi, C. America's water risk: Current demand and climate variability. Geophys. Res. Lett. 2015, 42, 2285-2293. [CrossRef]

31. Kwon, H.-H.; Lall, U. A copula-based nonstationary frequency analysis for the 2012-2015 drought in California. Water Resour. Res. 2016, 52, 5662-5675. [CrossRef]

32. Center for Climate and Resilience Research (CR) 2. The 2010-2015 Mega-Drought: A Lesson to the Future; Report for policymakers; (CR) 2: Santiago, Chile, 2015. (In Spanish)

33. Boisier, J.P.; Rondanelli, R.; Garreaud, R.D.; Muñoz, F. Anthropogenic and natural contributions to the Southeast Pacific precipitation decline and recent megadrought in central Chile. Geophys. Res. Lett. 2016, 43, 413-421. [CrossRef]

34. Garreaud, R.; Alvarez-Garreton, C.; Barichivich, J.; Boisier, J.P.; Christie, D.A.; Galleguillos, M.; LeQuesne, C.; McPhee, J.; Zambrano-Bigiarini, M. The 2010-2015 mega drought in Central Chile: Impacts on regional hydroclimate and vegetation. Hydrol. Earth Syst. Sci. Discuss. 2017, 21, 6307-6327. [CrossRef] 
35. Corporación Nacional Forestal (CONAF). Analisis de la afectacion y severidad de los incendios forestales ocurridos en enero y febrero de 2017 sobre los usos de suelo y los ecosistemas naturales presentes entre las regiones de Coquimbo y Araucanıa de Chile; Informe Tecnico; Corporacion Nacional Forestal Ministerio de Agricultura: Santiago, Chile, 2017.

36. Martınez-Harms, M.J.; Caceres, H.; Biggs, D.; Possingham, H.P. After Chile's fire, reforest private land. Science 2017, 356, 147-148. [CrossRef] [PubMed]

37. González, M.E.; Gómez-González, S.; Lara, A.; Garreaud, R.; Díaz-Hormazábal, I. The 2010-2015 Megadrought and its influence on the fire regime in central and south-central Chile. Ecosphere 2018, 9, e02300. [CrossRef]

38. Gonzalez-Hidalgo, J.C.; Brunetti, M.; de Luis, M. A new tool for monthly precipitation analysis in Spain: MOPREDAS database (monthly precipitation trends December 1945-November 2005). Int. J. Climatol. 2010, 31, 715-731. [CrossRef]

39. Guerreiro, S.B.; Kilsby, C.; Serinaldi, F. Analysis of time variation of rainfall in transnational basins in Iberia: Abrupt changes or trends? Int. J. Climatol. 2014, 34, 114-133. [CrossRef]

40. Vicente-Serrano, S.M. Spatial and temporal analysis of droughts in the Iberian Peninsula (1910-2000). Hydrol. Sci. 2006, 51, 83-97. [CrossRef]

41. Vicente-Serrano, S.M. Differences in spatial patterns of drought on different time scales: An analysis of the Iberian peninsula. Water Resour. Manag. 2006, 20, 37-60. [CrossRef]

42. Lesk, C.; Rowhani, P.; Ramankutty, N. Influence of extreme weather disasters on global crop production. Nature 2016, 529, 84-87. [CrossRef]

43. Guerreiro, S.B.; Kilsby, C.; Fowler, H.J. Assessing the threat of future megadrought in Iberia. Int. J. Climatol. 2017, 37, 5024-5034. [CrossRef]

(C) 2020 by the authors. Licensee MDPI, Basel, Switzerland. This article is an open access article distributed under the terms and conditions of the Creative Commons Attribution (CC BY) license (http://creativecommons.org/licenses/by/4.0/). 